\title{
Distribution and Forage Potential of Some Insect Taxa Sampled with Sweep Nets in the Flood Plains of a Coastal Ramsar Site in Ghana
}

\author{
Francis Gbogbo*, Daniel Osei Yeboah, Maxwell K. Billah \\ Department of Animal Biology and Conservation Science, University of Ghana, Legon \\ Email: ${ }^{*}$ gbogbo@ug.edu.gh
}

Received 2 December 2013; revised 2 January 2014; accepted 9 January 2014

Copyright (C) 2014 by authors and Scientific Research Publishing Inc.

This work is licensed under the Creative Commons Attribution International License (CC BY). http://creativecommons.org/licenses/by/4.0/

\begin{abstract}
Wetland insect communities are an important food source for waterbirds. Yet studies on insect communities in West African coastal wetlands-a major foraging area for wintering waterbirds of the East Atlantic and Mediterranean flyways-are generally limited. This study investigated the forage potential, micro-spatial and temporal distribution of insects swept from air and low vegetation in Sakumo II-a coastal Ramsar site in Ghana. Insects of the families Thripidae, Coccinellidae, Tetrigidae and Acrididae dominated the wetland. Based on prey yield and abundance, Acrididae, Coccinellidae and Tetrigidae appeared to be most promising source of food for waterbirds. Despite the high abundance of Thripidae, their low per capita biomass rendered them a less promising food source particularly to large sized waterbird species. Spatial and temporal abundance and distributions of insects along both the latitudinal and longitudinal axes of the lagoon were non-significant. In recognition of the diversity and abundance of insects on the wetland, there is the need to investigate the disparity in the utilisation of the various taxa by waterbird species.
\end{abstract}

\section{Keywords}

Insecta; Waterbirds; Distribution; Forage; Biomass

\section{Introduction}

Insects are one of the most diverse animal taxa on Earth and are found in many different habitat types. Their "Corresponding author.

How to cite this paper: Gbogbo, F., Yeboah, D.O. and Billah, M.K. (2014) Distribution and Forage Potential of Some Insect Taxa Sampled with Sweep Nets in the Flood Plains of a Coastal Ramsar Site in Ghana. Open Journal of Ecology, 4, $135-144$. http://dx.doi.org/10.4236/oje.2014.43015 
success has been linked to the structural diversity of flowering plants which provide habitat and food over most of the earth's land area [1]. Although wetland vegetations, such as mangroves, seaweeds and sea grasses generally provide a limited diversity in habitat structure, insects still abound on wetlands and their importance as food source for waterbirds cannot be overemphasised [2]-[7].

Although research on waterbird foraging ecology has proliferated in coastal West Africa as a result of the region's significance as wintering habitat for Palearctic migrant waterbirds, studies of the diversity, abundance, distribution and utilisation of insects by waterbirds are uncommon. According to [8] and [9], different species of waterbirds preferred different foraging microhabitats and utilised limited foraging patches. For instance, while some species of waterbirds preferred and were limited to shoreline habitats, others utilised only marginal water areas or dry vegetation areas [8] [9]. Many of these waterbirds, such as the Ringed Plover (Charadrius hiaticula), Grey Plover (Pluvialis squatarola), Curlew Sandpipers (Calidris ferruginea), and Wood Sandpiper (Tringa glareola) feed on insects in coastal Ghana [4] [9] [10]. It is therefore reasonable to hypothesise that the micro-spatial distribution of insects accounts for the disparities in the selection and utilisation of the foraging habitats of some waterbird species - but this has not been largely investigated. Also, wetlands are sensitive ecological areas and the importance of data on the abundance and distribution of wetland insects in assessing changes in wetland ecological status resulting from human use, climate change and pollution cannot be overemphasised. This paper examined the forage potential, micro-spatial and temporal distribution of insects collected with sweep nets in the flood plains of Sakumo II lagoon, a coastal Ramsar site in Ghana. As insects form a significant component of the diet of waterbirds [2] [3] [6] [7], it was predicted that significant variability exists in the distribution and abundance of insects in the micro spatial scale and that the variability determines the selection and use of micro habitats by waterbirds during foraging.

\section{Materials and Methods}

\subsection{Study Area}

The study was carried out at the Sakumo II Lagoon $\left(5^{\circ} 37^{\prime} \mathrm{N}, 0^{\circ} 02^{\prime} \mathrm{W}\right)$ (generally called Sakumo Lagoon). Sakumo II Lagoon is one of the five coastal Ramsar sites in Ghana, with a total conservation area of $13.4 \mathrm{~km}^{2}$. About $7 \mathrm{~km}^{2}$ of Sakumo II conservation area is made up of alluvial plain and this surrounds the brackish water lagoon of $3.5 \mathrm{~km}^{2}$ [11]. The area of the brackish water lagoon is however reduced to about $1 \mathrm{~km}^{2}$ during the dry season (Sep./Oct. to Mar./Apr.) [12].

The flora includes low-lying grasses such as Cyperus sp. and Paspalum sp. in most of the estuary bed and scanty remains of the Mangrove Avicennia sp. [13]. Many waterbird species forage in the flood plains and marginal waters of the lagoon with few species making use of the open water. According to [14], Sakumo II Lagoon serves as a habitat for about 70 species of waterbirds whose estimated aggregate maximum population is about 30,000. Flocks are usually dominated by Black-winged Stilts (Himantopus himantopus), Ringed Plovers (Charadrius hiaticula), Curlew Sandpipers (Calidris ferruginea), Greenshanks (Tringa nebularia), Common Tern (Sterna hirundo), Black Terns (Chlidonias niger) and Little Egrets (Egretta garzetta).

\subsection{Experimental}

The flood plain in the western bank of the lagoon, constituting the core foraging habitat of waterbirds on the wetland was divided into three zones based on the proximity to the sea. These include the 1) Southern Zone $\left(5^{\circ} 36^{\prime} 57.26 " \mathrm{~N}, 0^{\circ} 2^{\prime} 6.64 " \mathrm{~W}\right)$ which was the closest to the sea and hosts the mouth of the lagoon, 2) Northern zone $\left(5^{\circ} 37^{\prime} 41.04 " \mathrm{~N}, 0^{\circ} 2^{\prime} 27.76 " \mathrm{~W}\right)$ - the farthest from the sea, and which was the major point of fresh water discharge into the lagoon, and 3) Middle zone ( $\left.5^{\circ} 37^{\prime} 19.16 " \mathrm{~N}, 0^{\circ} 2^{\prime} 12.49^{\prime \prime} \mathrm{W}\right)$, sandwiched by the Northern and the Southern zones. Since the main source of fresh water inflow to the lagoon was in the Northern zone and the lagoon entered the sea in the southern zone, this zonal division marks the source to mouth gradient of the lagoon.

Each zone was further divided into three sites based on the proximity to the main body of the lagoon. These include 1) the marshy shoreline area with pockets of sedges and rushes in all the three zones, 2) the extensive intertidal area adjoining the marshy shoreline area which in all three zones was a bare mudflat interspaced with pockets of Sesuvium portulacastrum and 3) the semi-terrestrial area marking the maximum water edge of the lagoon which was relatively dry and covered with grass in all zones. Thus the three zones had similar vegetation structure consisting of pockets of sedges and rushes around their shoreline area adjoining to bare mudflat inter- 
spaced with pockets of Sesuvium portulacastrum bordered with a dry grassy area and therefore creating three psuedo-replicates each of the marshy shoreline, intertidal area and the semi-terrestrial areas to mark the shoreline to land gradient of the lagoon.

Sweeping of insects was carried out in the months of October and December 2011, and February 2012. These months fall within the dry season and as a result of the lack of rains, the vegetation of the individual zones and sites remain stable throughout the study as previous described by [10]. In each month, data were collected on two days such that the first sweeping was carried out in the first week of the month and the second, three days after. The sweeping was carried out between 0900 and $1500 \mathrm{~h}$ GMT by the same individual throughout the study. On each site, the sweeping involved wandering around and haphazardly sweeping insects from air and low vegetation to cover as much area as can be covered in 30 minutes. Thus an aggregate sweeping period of 90 minutes was obtain for each zone, four and a half hours per each sampling day, and 27 hours for the entire study.

Data collection on the first day of survey in each month began from the dry grassy semi-terrestrial area of the Northern Zone to the marshy shoreline area of the Northern Zone, through the marshy shoreline area of the Middle Zone to the dry grassy semi-terrestrial area of the Middle Zone and finally from the dry grassy semiterrestrial area of the Southern Zone to the marshy shoreline area of the Southern Zone. In order to reduce biases due to variation in daily weather conditions and fatigue, this order of sweeping was reversed on the second day of survey in each month, such that the sweeping began from the marshy shoreline area of the Southern Zone and ended at the dry grassy semi-terrestrial area of the Northern Zone.

Collected insect samples were euthanized in a large killing jar and stored in $70 \%$ ethanol in labelled vials. Sorting and identification were done in the laboratory after which specimens were oven dried at $55^{\circ} \mathrm{C}$ for 3 days and their weight taken.

\subsection{Data Analysis}

Abundance and biomass data from the nine sites were pooled in groups of three based on the latitudinal and longitudinal divisions. As indicated in the description of the study design, the division of each zone into 3 sites on the proximity to the main body of the lagoon created three sub-samples (i.e. psuedo-replicates) of the 1) the marshy shoreline area 2) intertidal area and 3) the semi-terrestrial area. These were combined and therefore not analyzed as multiple samples. Subsequently, data were analysed based on the lagoon's source-to-mouth and shoreline-to-land dimensions. Data were also analysed on temporal variations. Each data set was tested for normality, given that for a normally-distributed dataset, values of both Kurtosis/SE $\mathrm{Surt}_{\text {and }}$ and skewness $/ \mathrm{SE}_{\text {skew }}$ lies between -1.96 and +1.96 , (where $\mathrm{SE}_{\text {kut }}$ and $\mathrm{SE}_{\text {skew }}$ denotes standard errors of kurtosis and skewness, respectively [15].

Per capita biomass (PCB) was calculated as:

PCB $=$ total dry weight of the $i^{\text {th }}$ family $\div$ number of individuals belonging to the $i^{\text {th }}$ family.

The Shannon-Wiener index was used to determine the within habitat diversity where the value of the index is a direct measure of the diversity of the habitat with higher indices indicating higher diversity [16]. The Pielou's index (EH) measured the within habitat evenness where the degree of evenness of a habitat is indicated by the closeness of the EH value to 1 [16]. Sorensen's index (Cs) measured the multivariate families overlap among sampling areas where Cs of ' 1 ' implies complete similarity and " 0 " denotes complete dissimilarity. i.e. Cs $\geq 0.5$ suggests occurrence of high similarity and $\mathrm{Cs} \leq 0.5$ implies low levels of similarity [16].

\section{Result}

\subsection{General Abundance Biomass and Forage Potential}

A total of 930 individual insects comprising 9 Orders and 21 Families were collected over the study period (Table 1). Thysanoptera represented by the family Thripidae, was the most dominant insect family and constituted 38.39\% of the insect total abundance. This was followed by Coleoptera (35.27\%) and Orthoptera (18.81\%). The least occurring families included Hymenoptera, Lepidoptera, Phasmatodea, Hemiptera, Odonata, and Diptera, collectively constituting $7.54 \%$ of the arthropod total abundance. Among the Coleopterans, Coccinellidae dominated with $32.9 \%$ of the insect total abundance, while Tetrigidae (11.29\%) dominated the Orthopterans (Table 1).

The total biomass of all the captured insects put together was 10.38g of which Orthopterans constituted $61.8 \%$ and was dominated by Acrididae (49.31\%) and Tetrigidae (12.02\%) (Table 1). This was followed by the Order 
Table 1. Abundance and biomass values of insects swept in Sakumo II Lagoon between October 2011 and February 2012 (Total Biomass of all insects put together $=10.38 \mathrm{~g}$, total number of insects $=930$ ).

\begin{tabular}{|c|c|c|c|c|}
\hline Order & Family & Relative Abundance (\%) & \% of Total insect Biomass & Per Capita Biomass (g) \\
\hline \multirow[t]{3}{*}{ Thysanoptera } & Thripidae & 38.39 & 5.78 & $<0.01$ \\
\hline & Coccinellidae & 32.9 & 15.39 & 0.01 \\
\hline & Geotrupidae & 1.83 & 1.52 & 0.01 \\
\hline \multirow[t]{4}{*}{ Coleoptera } & Hydrophilidae & 0.32 & 0.28 & 0.01 \\
\hline & Silphidae & 0.11 & 0.04 & $<0.01$ \\
\hline & Kateritidae & 0.11 & 0.10 & 0.01 \\
\hline & Tetrigidae & 11.29 & 12.02 & 0.01 \\
\hline \multirow[t]{2}{*}{ Orthoptera } & Acrididae & 7.2 & 49.31 & 0.08 \\
\hline & Tettigoniidae & 0.32 & 0.47 & 0.02 \\
\hline \multirow{2}{*}{ Diptera } & Muscidae & 2.47 & 0.68 & $<0.01$ \\
\hline & Culicidae & 0.75 & 0.22 & $<0.01$ \\
\hline \multirow{2}{*}{ Odonata } & Epiophlebiidae & 2.15 & 6.19 & 0.03 \\
\hline & Coenagrionidae & 0.86 & 2.20 & 0.03 \\
\hline \multirow{4}{*}{ Hemiptera } & Miridae & 0.32 & 0.25 & 0.01 \\
\hline & Nepidae & 0.11 & 0.06 & 0.01 \\
\hline & Pentatomidae & 0.11 & 0.10 & 0.01 \\
\hline & Pyrrhocoridae & 0.11 & 0.08 & 0.01 \\
\hline Phasmatodea & Phyllidae & 0.22 & 1.59 & 0.08 \\
\hline Lepidoptera & Alucitidae & 0.22 & 0.81 & 0.04 \\
\hline \multirow{2}{*}{ Hymenoptera } & Heloridae & 0.11 & 0.70 & 0.07 \\
\hline & Apidae & 0.11 & 0.33 & 0.04 \\
\hline
\end{tabular}

Coleoptera which constituted $17.33 \%$ of the insect total biomass and dominated by Coccinellidae (15.39\%). Although Thysanoptera was the most dominant insect family in terms of numbers, it constituted only $5.78 \%$ of the total insect biomass. The families Acrididae and Phyllidae had the highest per capita biomass $(0.08 \mathrm{~g})$ followed by Heloridae (0.07 g), Alucitidae (0.04 g), Apidae (0.04 g) Epiophlebiidae (0.03 g) and Coenagrionidae (0.03 g). Thripidae, Silphidae, Muscidae and Culicidae had the lowest per capita biomass and would thus offer the least prey yield (consumable meat per individual) (Table 1).

\subsection{Micro-Spatial Distribution}

\subsubsection{Source-to-Mouth Gradient}

In relation to the distribution of insects along the lagoon's source to mouth gradient (Table 2), 14 families of insects were recorded in each of the Northern and Middle zones, and 11 in the Southern Zone. Shannon-Wiener index for the Northern, Middle and Southern zones were $1.30 \pm 0.19,1.49 \pm 0.65$, and $1.54 \pm 0.73$ (Table 3) respectively and thus indicating similarity in diversity (ANOVA $\mathrm{F}_{2,3}=0.09, \mathrm{p}>0.05$ ). Also, Pielou's index values of $0.46 \pm 0.19,0.58 \pm 0.29$ and $0.62 \pm 0.23$ were obtained respectively for the Northern, Middle and Southern zones (Table 3) and suggesting moderately even distribution of the insects among each of the three zones (ANOVA $F_{2,3}=0.36, p>0.05$ ). The Northern Zone recorded a Sorensen's index of 0.64 with both the Middle and Southern zones, while the Middle and Southern zones scored a Sorensen's Index of 0.72 and thus indicating that a high similarity in the community compositions of the insect in the three zones. Mean number of insects recorded in the Northern $(14 \pm 30)$, Middle $(17 \pm 40)$ and Southern $(19 \pm 31)$ zones were statistically similar $\left(\mathrm{H}_{2 ; 0.05}=0.518, \mathrm{p}>0.05\right)$. 
Table 2. Distribution of swept insects along the source-to-mouth gradient of Sakumo II Lagoon (Data: October 2011 and February 2012).

\begin{tabular}{|c|c|c|c|}
\hline \multirow{2}{*}{ Family } & \multicolumn{3}{|c|}{ Total number of insects collected } \\
\hline & Northern & Middle & Southern \\
\hline Coccinellidae & 82 & 156 & 68 \\
\hline Geotrupidae & 10 & 3 & 4 \\
\hline Hydrophilidae & 3 & 0 & 0 \\
\hline Silphidae & 1 & 0 & 0 \\
\hline Kateritidae & 1 & 0 & 0 \\
\hline Tettigoniidae & 3 & 0 & 0 \\
\hline Tetrigidae & 25 & 47 & 33 \\
\hline Thripidae & 122 & 108 & 127 \\
\hline Acrididae & 13 & 30 & 24 \\
\hline Epiophlebiidae & 9 & 6 & 5 \\
\hline Coenagrionidae & 3 & 1 & 4 \\
\hline Muscidae & 12 & 3 & 8 \\
\hline Culicidae & 3 & 4 & 0 \\
\hline Miridae & 0 & 1 & 2 \\
\hline Nepidae & 0 & 1 & 0 \\
\hline Pentatomidae & 0 & 0 & 1 \\
\hline Pyrrhocoridae & 0 & 0 & 1 \\
\hline Heloridae & 0 & 1 & 0 \\
\hline Apidae & 0 & 1 & 0 \\
\hline Phyllidae & 2 & 0 & 0 \\
\hline Alucitidae & 0 & 2 & 0 \\
\hline TOTAL & 289 & 364 & 277 \\
\hline
\end{tabular}

Table 3. Ecological diversity values of swept insect taxa based on spatial and temporal scale.

\begin{tabular}{|c|c|c|c|c|c|c|c|c|c|}
\hline \multirow{2}{*}{$\begin{array}{c}\text { Ecological } \\
\text { diversity }\end{array}$} & \multicolumn{3}{|c|}{ Source-to-Mouth distribution } & \multicolumn{3}{|c|}{ Shoreline-to-land distribution } & \multicolumn{3}{|c|}{ Temporal Distribution } \\
\hline & $\begin{array}{l}\text { Northern } \\
\text { Zone }\end{array}$ & $\begin{array}{l}\text { Middle } \\
\text { Zone }\end{array}$ & $\begin{array}{l}\text { Sourthern } \\
\text { Zone }\end{array}$ & $\begin{array}{l}\text { Marshy } \\
\text { Shoreline }\end{array}$ & $\begin{array}{l}\text { Intertidal } \\
\text { Area }\end{array}$ & $\begin{array}{c}\text { Dry grassy } \\
\text { semi-terrestrial } \\
\text { Area }\end{array}$ & October & December & February \\
\hline Shannon-Weiner & $1.30 \pm 0.19$ & $1.49 \pm 0.65$ & $1.54 \pm 0.73$ & $1.54 \pm 0.61$ & $1.82 \pm 0.55$ & $1.22 \pm 0.95$ & $1.59 \pm 0.44$ & $1.63 \pm 0.64$ & $1.23 \pm 0.51$ \\
\hline Pielou & $0.46 \pm 0.19$ & $0.58 \pm 0.29$ & $0.62 \pm 0.23$ & $0.57 \pm 0.9$ & $0.66 \pm 0.34$ & $0.59 \pm 0.27$ & $0.64 \pm 0.37$ & $0.56 \pm 0.30$ & $0.49 \pm 0.26$ \\
\hline
\end{tabular}

\subsubsection{Shoreline-to-Land Gradient}

Table 4 shows the distribution of insects based on the shoreline-to-land gradient of the lagoon. A total of 15 families of insects were recorded in the marshy shoreline, 16 in the Intertidal area and 11 in the dry grassy area yielding a Sorenson index of 0.71 for the shoreline-Intertidal zone, 0.54 for the Shoreline-dry grass area, and 0.52 for the dry grassy area-intertidal zone indicating that the community composition of insect families was more similar between the shoreline and intertidal area than the dry grassy semi-terrestrial area. In relation to diversity, Shannon-Wiener index of $1.54 \pm 0.61,1.82 \pm 0.55$, and $1.22 \pm 0.95$, were recorded respectively for the Marshy shoreline, Intertidal area and the Dry grassy semi-terrestrial area (Table 3) and were statistically similar (ANOVA $F_{2,3}=1.16, \mathrm{p}>0.05$ ). Pielou's index for the Marshy shoreline, Intertidal area and the Dry grassy 
Table 4. Distribution of swept insects along the shoreline-to-land gradient of Sakumo II Lagoon (Data: October 2011 and February 2012).

\begin{tabular}{|c|c|c|c|}
\hline \multirow{2}{*}{ Family } & \multicolumn{3}{|c|}{ Total number of insects collected } \\
\hline & Marshy shoreline & Intertidal Area & Dry grassy Semi-terrestrial area \\
\hline Coccinellidae & 235 & 39 & 32 \\
\hline Geotrupidae & 15 & 1 & 1 \\
\hline Hydrophilidae & 3 & 0 & 0 \\
\hline Silphidae & 1 & 0 & 0 \\
\hline Kateritidae & 1 & 0 & 0 \\
\hline Tettigoniidae & 3 & 0 & 0 \\
\hline Tetrigidae & 60 & 1 & 44 \\
\hline Thripidae & 187 & 8 & 162 \\
\hline Acrididae & 31 & 3 & 33 \\
\hline Epiophlebiidae & 6 & 13 & 1 \\
\hline Coenagrionidae & 3 & 3 & 2 \\
\hline Muscidae & 22 & 1 & 0 \\
\hline Culicidae & 3 & 4 & 0 \\
\hline Miridae & 1 & 2 & 0 \\
\hline Nepidae & 0 & 1 & 0 \\
\hline Pentatomidae & 0 & 1 & 0 \\
\hline Pyrrhocoridae & 0 & 1 & 0 \\
\hline Heloridae & 0 & 1 & 0 \\
\hline Apidae & 0 & 1 & 0 \\
\hline Phyllidae & 0 & 0 & 2 \\
\hline Alucitidae & 1 & 1 & 0 \\
\hline TOTAL & 572 & 81 & 277 \\
\hline
\end{tabular}

semi-terrestrial (Table 3) were $0.57 \pm 0.9,0.66 \pm 0.34$ and $0.59 \pm 0.27$ and were statistically similar (ANOVA $\left.F_{2,3}=0.48, p>0.05\right)$. Mean insect abundance for the Marshy shoreline (27 \pm 63 ), Intertidal area $(4 \pm 9)$ and the Dry grassy $(19 \pm 36)$ were not significant $\left(\mathrm{H}_{2 ; 0.05}=4.118, \mathrm{p}>0.05\right)$.

\subsubsection{Temporal Distribution}

The number of insects recorded in the study area based on the temporal scale is presented in Table 5. October recorded 12 insect families compared to 18 and 13, respectively in December and February. Similarly ShannonWiener index (Table 3) for October was $1.59 \pm 0.44$, compared to December $(1.63 \pm 0.64)$ and February $(1.23 \pm$ 0.51 ) and were statistically similar (ANOVA $F_{2,3}=0.11, \mathrm{p}>0.05$ ). Mean abundance of insects in October $(15 \pm$ 35), December $(17 \pm 44)$ and February $(12 \pm 24)$ were not significantly different $\left(\mathrm{H}_{2: 0.05}=1.279, \mathrm{p}>0.05\right)$. Pielou's index values (Table 3) were $0.64 \pm 0.37,0.56 \pm 0.30$ and $0.49 \pm 0.26$, respectively for the months of October, December and February indicating a moderately even distribution of insect families among the months (ANOVA $F_{2,3}=0.53, \mathrm{p}>0.05$ ). Sorenson index of 0.80, 0.72 and 0.65 were obtained respectively for October, December and February indicating similar community composition of the insect families.

\section{Discussion}

Several families of insect have been identified to constitute important food for waterbirds [3] [6] [7]. In the coast of Ghana, waterbird species such as Ringed Plover (Charadrius hiaticula), Grey Plover (Pluvialis squatarola), 
Table 5. Distribution of swept insects based on the temporal scale in the Sakumo II Lagoon (Data: October 2011 and February 2012).

\begin{tabular}{|c|c|c|c|}
\hline \multirow{2}{*}{ Family } & \multicolumn{3}{|c|}{ Temporal Distribution } \\
\hline & October & December & February \\
\hline Coccinellidae & 126 & 88 & 92 \\
\hline Geotrupidae & 8 & 5 & 4 \\
\hline Hydrophilidae & 1 & 1 & 1 \\
\hline Silphidae & 0 & 1 & 0 \\
\hline Kateritidae & 0 & 1 & 0 \\
\hline Tettigoniidae & 1 & 2 & 0 \\
\hline Tetrigidae & 45 & 26 & 34 \\
\hline Thripidae & 102 & 194 & 61 \\
\hline Acrididae & 16 & 15 & 36 \\
\hline Epiophlebiidae & 7 & 3 & 10 \\
\hline Coenagrionidae & 4 & 3 & 1 \\
\hline Muscidae & 3 & 11 & 9 \\
\hline Culicidae & 0 & 6 & 1 \\
\hline Miridae & 2 & 1 & 0 \\
\hline Nepidae & 0 & 1 & 0 \\
\hline Pentatomidae & 0 & 1 & 0 \\
\hline Pyrrhocoridae & 0 & 1 & 0 \\
\hline Heloridae & 0 & 0 & 1 \\
\hline Apidae & 0 & 0 & 1 \\
\hline Phyllidae & 0 & 0 & 2 \\
\hline Alucitidae & 1 & 1 & 0 \\
\hline TOTAL & 316 & 361 & 253 \\
\hline
\end{tabular}

Curlew Sandpipers (Calidris ferruginea), and Wood Sandpiper (Tringa glareola) are known to depend on various insects including many of the insect families obtained in this study [4] [9] [10]. This study established insects of the families Thripidae, Coccinellidae, Tetrigidae and Acrididae as the four most dominant insect families collected from air and vegetation in Sakumo II Lagoon. In relation to forage potential to inhabiting waterbirds, insects of the families Acrididae and Phyllidae had the highest per capita biomass and would thus produce the greatest prey yield. However, while Acrididae abound on the wetland and constitute (7.2\%) of the insects, Phyllidae was among the least occurring and it might be an insignificant food source to the birds. Although Thripidae abound on the wetlands, it constituted only $6 \%$ of the total insect biomass. Also the per capita biomass of Thripidae was negligible and comparable to that of Silphidae, Muscidae and Culicidae, each of which constituted less than $1 \%$ of the total insect abundance. Insects of the families Coccinellidae and Tetrigidae which were dominant after Thripidae, constituted approximately $15 \%$ and $12 \%$, respectively of the total insect biomass. The per capita biomass of Coccinellidae and Tetrigidae were also comparable to those of many other insects on the wetland, and higher than that of Thripidae.

The Optimum Foraging Theory predicts that foraging organisms reject small prey items to maximise their net energy gain [17] [18]. Indeed, [19] reported Red Knots (Calidris canutus) to have rejected Sand Gappers smaller than $0.4 \mathrm{~cm}$ though they occurred in densities of thousands of individuals per $\mathrm{m}^{2}$, while Eurasian Curlews ( $\mathrm{Nu}$ menius arquata) did the same with shore crabs less than $1 \mathrm{~cm}$ [20]. However, the selectivity of a specific prey for consumption also depends on the size of the predator [21]. The waterbird species in Sakumo II range from large sized species like the Grey Heron (Ardea cinerea) to the small Little Stint (Calidris minuta) [22]. Thus the 
minimum prey yield requirement of each species may differ and there is the possibility that while large sized birds would reject the small insects, they may be eaten by the small sized birds and this may account for the similarity in the diversity and abundance of the insects in both the latitudinal and longitudinal axes of the lagoon.

However, though small waterbird species may be willing to accept low prey yield, the per capita biomass and abundance values obtained in this study generally suggested Acrididae, Coccinellidae and Tetrigidae as the insect families that might be of major forage significance to inhabiting waterbirds in Sakumo II. Acrididae and Tetrigidae are Orthopterans while Coccinellidae are Coleoptera. These two orders are among the major orders of insects identified to dominate the diet of terns in North Ameriaca [3]. Although Thripidae occurred in large numbers, individuals in the family have little to offer in terms of prey yield and this may limit its potential as a food source particularly to the large sized waterbirds.

A previous study [5] identified Agelenidae and Formicidae as the dominant ground arthropod families in Sakumo II Lagoon with the former and Gryllidae being the most promising source of food to waterbirds. Thus a synergy of this work and that of [5] indicate Acrididae, Coccinellidae, Tetrigidae Gryllidae and Agelenidae as the arthropod families that are of most significance to waterbird foraging and that although Thripidae and Formicidae abound in Sakumo II Lagoon, they are of little value to waterbird foraging due to their low per capita biomass.

Several environmental factors including wind, salinity and vegetation exhibit strong gradients in lagoons due to their proximity to the sea [23]. These gradients generally influence distribution of organisms on the microspatial scale [23] [24]. The similarity in the abundance, diversity, and community composition of insects among the lagoon's source, middle and mouth as well as its shoreline, intertidal area and the dry grassy terrestrial areas are indications that the distribution of insects on the spatial scale might not be affected by these gradients. These observations also indicated that the entire flood plain of the lagoon is of a similar patch quality in terms of insect abundance and diversity. Thus the limited ranges and site preferences exhibited by foraging waterbird species in Ghana's coastal lagoons [9] are not governed by disparities in the distribution of the insects.

The wintering period of Palearctic migrant waterbirds in coastal West Africa ranges from September to April [25]. Since many waterbirds arrive by October and feed voraciously to build up energy reserves for the return migratory flight, food resources could be depleted over time [26]-[28]. The similarity in the community composition, abundance and diversity of the insects through the months of the study suggests that the presence of the birds neither affect the community composition of the insects nor depleted their abundance. In recognition of the abundance and diversity of insect families on the coast of Ghana as clearly demonstrated in this study, there is the need to investigate the disparity in the utilisation of the various insect taxa by by the different waterbird species.

\section{Conclusion}

Using the sweeping method, insects in the flood plains of Sakumo II Lagoon were observed to be dominated by Thripidae, Coccinellidae, Tetrigidae and Acrididae. Spatial and temporal abundance and distributions of insects along both the latitudinal and longitudinal axes of the lagoon were insignificant. Based on abundance values and per capita biomass, families appearing to be most important to waterbird foraging include Acrididae, Coccinellidae and Tetrigidae. Despite their high relative abundance, low per capita biomass predisposed Thripidae as a less important food source particularly for large sized waterbirds.

\section{Acknowledgements}

We acknowledge the contributions of Mr Davis Henry of the African Regional Postgraduate Programme in Insect Sciece (ARPPIS), and S. K. B Boni of the Department of Animal Biology and Conservation Science (DABCS), University of Ghana. The support of Mr. Romulus Langpuur, Adaworomah Bernard Bobson, Ernest Asante and Grace Rechelle Brown-Engmann during the field work cannot go unnoticed.

\section{References}

[1] Novotny, V., Drozd, P., Miller, S.E., Kulfan, M., Janda, M., Basset, Y. and Weiblen, G.D. (2006) Why Are There So Many Species of Herbivorous Insects in Tropical Rainforests? Science, 313, 1115-1118. 
http://dx.doi.org/10.1126/science.1129237

[2] Liordos, V. (2010) Foraging Guilds of Waterbirds Wintering in a Mediterranean Coastal Wetland. Zoological Studies, 49, 311-323.

[3] Mauco, L., Marco, F. and Bo, S.A. (2001) Food and Feeding Biology of the Common Tern during the Non-Breeding Season in Samborombon Bay, Beunos Aires, Argentina. Waterbird, 24, 89-96.

[4] Gordon, I and Cobblah, M. (2000) Insects of the Muni-Pomadze Ramsar Site. Biodiversity \& Conservation, 9, 479486. http://dx.doi.org/10.1023/A:1008910629152

[5] Gbogbo, F., Langpuur, R. and Billah, M.K. (2012) Forage Potential, Micro-Spatial and Temporal Distribution of Ground Arthropods in the Flood Plain of a coastal ramsar Site in Ghana. African Journal of Science and Technology, 12, 80-88.

[6] Batzer, D.P. (1996) Ecology of Insect Communities in Non-Tidal Wetlands. Annual Review of Entomology, 41, 75-100. http://dx.doi.org/10.1146/annurev.en.41.010196.000451

[7] Batzer, D.P, McGee, M., Resh, V.H. and Smith, R.R. (1993) Characteristics of Invertebrates Consumed by Mallards and Prey Response to Wetland Flooding Schedules. Wetlands, 13, 4149. http://dx.doi.org/10.1007/BF03160864

[8] Suapim, R.H., Attuquayefio, D.K., Gbogbo, F. and Owusu, E.H. (2007) Aspects of the Feeding Ecology of Wintering Waterbirds on the Densu Delta Ramsar Site, Ghana. Ghana Journal of Science, 42, 17-34.

[9] Ntiamoa-Baidu, Y., Piersma, T., Wiersma, P., Poot M., Battley, P. and Gordon, C. (1998) Habitat Selection, Daily Foraging Routines and Diet of Waterbirds in Coastal Lagoons in Ghana. Ibis, 140, 89-103.

http://dx.doi.org/10.1111/j.1474-919X.1998.tb04545.x

[10] Piersma, T. and Ntiamoa-Baidu, Y. (1995) Waterbird Ecology and the Management of Coastal Wetlands in Ghana, NIOZ Report 1996-6, Netherlands, 105.

[11] Wetland International (1998) Coastal Wetland Management Project, Wildlife Department. www.wetlands.org/reports/ris/1GH004en.pdf

[12] Pauly, D. (1975) On the Ecology of a Small West African Lagoon. Berichte der Deutschen Wissenschaftlichen Kommission fur Meeresforschung, 24, 46-62.

[13] Oteng-Yeboah, A.A. (1999) Biodiversity Studies in Three Coastal Wetlands in Ghana West Africa. Journal of the Ghana Science Association, 3, 147-149.

[14] BirdLife International (2012) Important Bird Areas Factsheet: Sakumo Lagoon Ramsar Site. http://www.birdlife.org

[15] Ashcroft, S. and Pereira, C. (2003) Practical Statistics for the Biological Science: Simple Pathway to Statistical Analyses. Palgrave Macmillan, New York, 167.

[16] Magurran, A.E. (1988) Ecological Diversity and Its Measurements. Princeton University Press, New Jersey, 179. http://dx.doi.org/10.1007/978-94-015-7358-0

[17] Charnov, E.L. (1976) Optimal Foraging, the Marginal Value Theorem. Theoretical Population Biology, 9, $129-136$. http://dx.doi.org/10.1016/0040-5809(76)90040-X

[18] Yahnke, C.J. (2006) Optimal Foraging Theory: Using Bird Predation on Goldenrod Galls. The American Biology Teacher, 68, 471-475. http://dx.doi.org/10.1662/0002-7685(2006)68[471:TOFTUB]2.0.CO;2

[19] Van de Kam, J., Ens, B., Piersma, T. and Zwarts, L. (2004) Shorebirds-An Illustrated Behavioural Ecology. KNNV, Netherlands, 368.

[20] Bloksma, J. Ens, B.J. and de Vries, M. (1979). Voedseloecologie van de Wulp op het Fries Wad. Student Report, Zoological Laboratory, University of Groningen, Groningen.

[21] Scharf, F.S., Juanes, F. and Rountree, R.A. (2000) Predator Size-Prey Size Relationships of Marinefish Predators: Interspecific Variation and Effects of Ontogeny and Body Size on Trophic-Niche Breadth. Marine Ecology Progress Series, 208, 229-248. http://dx.doi.org/10.3354/meps208229

[22] Gbogbo, F. (2007) The Importance of Unmanaged Wetlands to Waterbirds in Coastal Ghana. African Journal of Ecology, 45, 599-606. http://dx.doi.org/10.1111/j.1365-2028.2007.00778.x

[23] Montague, C.L. and Ley, J.A. (1993) A Possible Effect of Salinity Fluctuation on Abundance of Benthic Vegetation and Associated Fauna in Northeastern Florida Bay. Estuaries, 16, 703-717. http://dx.doi.org/10.2307/1352429

[24] Gordon, C. (2000) Hypersaline Lagoons as Conservation Habitats: Macro-Invertebrates at Muni Lagoon, Ghana. Biodiversity and Conservation, 9, 465-478. http://dx.doi.org/10.1023/A:1008906503227

[25] Ntiamoa-Baidu, Y. (1991) Seasonal Changes in the Importance of Coastal Wetlands in Ghana for Wading Birds. Biological Conservation, 57,139-158. http://dx.doi.org/10.1016/0006-3207(91)90135-V

[26] Landys-Ciannelli, M.M., Piersma, T. and Jukema, J. (2003) Strategic Size Changes of Internal Organs and Muscle Tissues in the Bar-Tailed Godwit during Fat Storage on a Spring Stopover Site. Functional Ecology, 17, 151-159. 
http://dx.doi.org/10.1046/j.1365-2435.2003.00715.x

[27] Battley, P.F., Piersma, T., Dietz, M.W., Tang, S., Dekinga, A. and Hulsman, K. (2000) Empirical Evidence for Differential Organ Reductions during Trans-Oceanic Bird-Flight. Biological Sciences, 267, 191-195. http://dx.doi.org/10.1098/rspb.2000.0986

[28] Piersma, T. and Jukema, J. (2002) Contrast in Adaptive Mass Gains: Eurasian Golden Plovers Store Fat before Midwinter and Protein before Pre-Breeding Flight. Proceedings of the Royal Society of London, 269, 1101-1105. http://dx.doi.org/10.1098/rspb.2002.1990 